ORIGINAL ARTICLE / ARTIGO ORIGINAL

\title{
Comparison of risk and protective factors for chronic diseases in the population with and without health insurance in the Brazilian capitals, 2011
}

\author{
Comparação dos fatores de risco e proteção de doenças crônicas na \\ população com e sem planos de saúde nas capitais brasileiras, 2011
}

Deborah Carvalho Malta', Regina Tomie Ivata Bernal"

\begin{abstract}
Introduction: The article compares the risk and protective factors for Non-communicable Diseases (NCD), referred morbidity and access to preventive examinations in the population with and without health insurance in all Brazilian State capitals. Methods: The study population consists of adults ( $\geq 18$ years old) living in households with landlines in 26 Brazilian State capitals and the Federal District. Estimates of selected variables are presented according to possession of health plans ("Yes" or "No") and sex. A post-stratification was performed according to age, gender and education in both populations, and prevalence ratios were calculated, adjusted for age and sex between people with and without health insurance for the risk and protective factors for NCDs. Results: A total of 54,099 people at the age of 18 or older were evaluated, $47.4 \%$ of them were beneficiaries of health plans. The coverage of health insurance tends to increase with age and level of education. Compared to non-beneficiaries of health plans, beneficiaries were more likely to have protective factors, such as healthy eating, physical activity, coverage tests, such as mammography and Pap test, and lower prevalence of risk factors such as smoking, physical inactivity, poor health assessment and hypertension. Alcohol abuse, consumption of excessively fat meats, overweight, obesity and diabetes were not associated with the variable possession of health insurance. When controlled by education, individuals who have health insurance generally have better indicators. Conclusion: This information is important to establish measures for reducing differences among people with and without health insurance.
\end{abstract}

Keywords: Chronic Disease. Health plans. Smoking. Papanicolaou smear. Mammography. Population surveys.

'Department of Non-Communicable Diseases Surveillance and Health Promotion, Health Surveillance Secretariat, Ministry of Health - Brasília (DF), Brazil.

"Center for Epidemiological Research in Nutrition and Health of Universidade de São Paulo - São Paulo (SP), Brazil.

Corresponding author: Deborah Carvalho Malta. Departamento de Vigilância de Doenças e Agravos Não Transmissíveis e Promoção da Saúde, Secretaria de Vigilância em Saúde, Ministério da Saúde. SAF Sul, Trecho 2, Lote 5/6, Torre I, Edifício Premium, Sala 14, Térreo, CEP: 70070-600, Brasília, DF, Brasil. E-mail: deborah.malta@saude.gov.br

Conflict of interests: nothing to declare - Financing source: none. 
RESUMO: Introdução: O artigo compara os fatores de risco e proteção de Doenças Crônicas Não Transmissíveis (DCNT), morbidade referida e acesso a exames preventivos na população com e sem planos de saúde nas capitais brasileiras. Métodos: A população de estudo é composta por adultos ( $\geq 18$ anos) moradores de residências com telefones fixos nas 26 capitais dos estados brasileiros e no Distrito Federal. As estimativas das variáveis selecionadas são apresentadas segundo planos de saúde ("Sim" ou "Não") e sexo. Foi realizada pós-estratificação segundo idade, sexo e escolaridade nas duas populações, e foram calculadas as razões de prevalência ajustadas por idade e sexo para os fatores de risco e proteção de DCNT. Resultados: Foram avaliadas 54.099 pessoas com 18 ou mais anos de idade, sendo 47,4\% beneficiários de planos de saúde. A cobertura de planos de saúde tende a aumentar com a idade e escolaridade. Os beneficiários de planos apresentaram maior chance de ter fatores de proteção, como alimentação saudável, prática de atividade física, cobertura de exames, como mamografia e Papanicolau, e menor prevalência de fatores de risco, como tabagismo, inatividade física, avaliação de saúde ruim e hipertensão arterial. O consumo de bebida alcoólica de forma abusiva, o consumo de carne com excesso de gordura, excesso de peso, obesidade e diabetes não tiveram associação com a variável posse de plano de saúde. Quando controlados por escolaridade, os indivíduos que têm planos de saúde geralmente apresentam melhores indicadores. Conclusão: Essas informações são importantes para reduzir iniquidades entre a população com e sem plano de saúde.

Palavras-chave: Doenças crônicas. Planos de saúde. Tabagismo. Papanicolau. Mamografia. Inquéritos populacionais.

\section{INTRODUCTION}

The main causes of morbimortality among Brazilian adults are the Chronic Non-Communicable Diseases (NCD), especially conditions of the circulatory system, neoplasms, chronic respiratory diseases and diabetes, which are in charge of $72 \%$ of deaths in the country ${ }^{1,2}$.

The impact of risk and protective factors on mortality caused by NCD can be observed by deaths that are attributed to or prevented by each factor. According to the World Health Organization (WHO), the insufficient intake of fruits, vegetables and greens is annually responsible for one third of heart ischemic diseases and about $20 \%$ of all gastrointestinal cancers in the world. Arterial hypertension, which is the main risk factor for cardiovascular diseases, causes about 7.5 million deaths/years, followed by smoking, physical inactivity, overweight/obesity, high cholesterol and abusive alcohol consumption. On the other hand, the regular practice of physical activities reduces the risk of cardiovascular diseases, including arterial hypertension, diabetes, breast cancer, colon/rectal cancer and depression, besides helping weight control ${ }^{3}$.

The NCDs have led to a high number of premature deaths, loss in quality of life and high level of limitation for individuals, besides causing negative economic impacts for families, communities and the society in general, which resulted in the aggravation of social inequities, poverty and social inequalities ${ }^{3}$. 
The NCD epidemic has affected mostly people with low income, since they are more exposed to risk factors and because they have less access to health services ${ }^{3,4}$. There are important differences in the distribution of morbimortality of NCDs, according to socioeconomic factors, such as education, occupation, income, gender and ethnicity, which results in different access to services, consumption patterns, among others ${ }^{1-3}$.

Studies have pointed out to a positive correlation between the access to health services and the purchasing power of the population. Data from the National Household Survey (PNAD) indicated that $49.7 \%$ of people with lower family income declared having seen a doctor in the past 12 months, but this number increased to $78.3 \%$ among people with family income superior to 20 minimum wages ${ }^{5}$. PNAD also showed that, the higher the family income, the higher the chances of having a health insurance plan. In the population with family income inferior to one minimum wage, the coverage of health plans was of about $3 \%$, but the coverage increased to $83.8 \%$ for those who received 20 minimum wages or more 5 . Previous studies from the Telephone Survey Surveillance System for Risk and Protective Factors for Chronic Diseases (Vigitel) pointed out that the population with health plans tends to have more access to preventive cancer examinations, such as the Pap test and mammography ${ }^{6}$. The Behavior Risk Factor Surveillance System (BRFSS) has publicized frequent analyses with the American population, comparing risk factors for NCDs among populations covered and not covered by health insurance plans. The results show that populations with health plans tend to have more access to preventive examinations, higher prevalence of protective factors, such as healthy diet and physical activities, and lower prevalence of risk factors, such as smoking ${ }^{7,8}$.

In Brazil, these national studies about risk factors of NCDs, such as dietary habits, physical activity, use of tobacco and alcohol and access to examinations in the population with and without health plans are still lacking. Studies conducted in Belo Horizonte show important differences between these populations, always associating higher prevalence of risk factors to populations that are not covered by health plans ${ }^{9}$.

Data on risk factors of NCDs began to be monitored in Brazil in 2006 by means of the Telephone Survey Surveillance System for Risk and Protective Factors for Chronic Diseases (Vigitel). The survey is conducted annually in all of the 26 Brazilian State capitals and in the Federal District, with the adult population $(\geq 18 \text { years old })^{10}$. Among the indicators that are proxy of socioeconomic status, we indicate schooling and the variable health insurance plan, included in 2008. The latter allows a specific look to the population that is beneficiary of health plans in the 26 capitals and in the Federal District.

This article compares the risk and protective factors of NCDs, referred morbidity and access to preventive examinations in the population with and without health plans in the set of Brazilian capitals. This is the first analysis, in all of the capitals, which compares a set of indicators from the Vigitel base in the population with and without health plans, being justified by the importance of monitoring indicators of risk and protective factors of NCDs, morbidities and access to preventive examinations in different social segments, in order to induce public policies of promotion and prevention and to promote equity. 


\section{METHODS}

This analysis refers to a cross-sectional population study that assesses the adult population $(\geq 18$ years old) living in the capitals of the 26 Brazilian states and in the Federal District. Vigitel uses probability samples of the adult population ( $\geq 18$ years old) from the registration of landlines in the cities, made available annually by the main landline companies in the country. Five thousand landlines were raffled in each city, which were divided in replicas (or sub-samples) of 200 lines each in order to identify the eligible lines, that is, active household lines. After confirming the eligibility of the line, the inhabitant to be interviewed was selected.

The data base from Vigitel 2011 was used, considering the comparison group composed of adults with and without health plans. The rake method ${ }^{11,12}$ was used to calculate post-stratification weights, using an external source of data concerning the Brazilian population. In the construction of post-stratification weights, estimates of age, sex and schooling of the population projected for the year of the study were used. The rake method uses the distribution of absolute frequencies of age group (18 to $24 ; 25$ to $34 ; 35$ to 44 ; 45 to $54 ; 65$ years old or more), sex (male, female), schooling ( 0 to $7 ; 8$ to $10 ; 11$ to $13 ; 14$ years or more) of the population, being weighed by sampling weights. Weights were calculated in the SAS software, using the macro sasRakinge.sas, made available by Izrael et al. ${ }^{13}$.

The Vigitel questionnaire involves 94 questions, divided into modules:

- Demographic and socioeconomic characteristics of individuals;

- Diet pattern and physical activity;

- Reported weight and height;

- Consumption of cigarettes and alcohol;

- Self-evaluation of health status and reported morbidity.

The interview of Vigitel is based on the system of telephone interviews assisted by computer, in which questions are read on the computer screen, and answers are registered directly in electronic mean, thus enabling the automatic skipping of invalid questions resulting from previous answers ${ }^{10}$.

The following risk factors of NCDs were studied: prevalence of smokers ( $\%$ of smokers / number of interviewed individuals, former smokers/number of individuals who quit smoking); excess weight (Body Mass Index $\geq 25 \mathrm{~kg} / \mathrm{m}^{2}$ ) and obesity (Body Mass Index $\geq 30 \mathrm{~kg} / \mathrm{m}^{2}$ ); intake of meats with excessive fat (red meat with visible fat or chicken with skin); regular consumption of soft drinks or artificial juice (five or more days a week); physical inactivity (individuals who did not practice any physical activity during their free time in the past three months, who do not perform intensive physical efforts at work, who do not commute to work or school on foot or by bicycle, or who are not in charge of cleaning their houses); abusive consumption of alcohol (four or more doses for women and five or more doses for men at the same occasion in the past 30 days, considering as a dose of alcohol one dose of distilled drinks, one can of beer or one glass of wine); driving a motorized vehicle after drinking any amount of alcohol; self-evaluation of poor health status; and referred morbidities (previous 
medical diagnosis of arterial hypertension and diabetes). The presented protective factors were: recommended consumption (five or more daily portions, on five or more weekdays) of fruits and vegetables; regular intake of beans (five or more days a week); recommended practice of physical activity during free time (practice of at least 150 minutes a week of mild or moderate physical activity, or at least 75 minutes of a week of vigorous physical activity, regardless of the number of days in which the activity is practiced during the week); performance examinations for the early detection of cancer among women (mammography for women aged from 50 to 69 years old and Pap test for women aged from 25 to 59 years old). Such indicators were calculated and the denominator was the total number of interviewed adults, except for those concerning specific age and sex.

The multiple logistic regression model was used:

$\left(\log \left\{\frac{\pi(x)}{1-\pi(x)}\right\}=\beta_{1}+\beta_{2} x_{2}+\ldots+\beta_{p} x_{p}\right)^{3}$,

in which $\pi(x)$ expresses the probability of access to health insurance plans, given the $x_{p}$ characteristics (age group and schooling years), in order to identify the profile. Explanatory variables are qualitative, and the first category is considered as a reference. Results from the multiple logistic regression are expressed by odds ratio (OR) for one specific $x_{p}$ and reference categories. The odds ratio equals to 1 indicates that the chance is equally likely in both groups. Values higher than lindicate how much higher the chance is in the first group, and values lower than 1 indicate how much lower the chance is in the first group in relation to the second group ${ }^{14}$. The frequencies of risk and protective factors of NCDs with and without health plans were compared, in the set of 26 capitals and the Federal Districted. The OR estimated by the logistic regression model between those who have and do not have health plans was calculated. Risk and protective factors of NCDs in the population with and without health plans were also analyzed, according to schooling strata in the set of 26 capitals and the Federal District. In all of the performed analyses, the final weight was considered, which is composed by the sampling weight and the post-stratification weight.

The Vigitel survey was approved by the National Human Ethics Research Committee, from the Ministry of Health. The signature of the Informed Consent Form, in this case, was replaced by the verbal consent of the interviewee at the time of the phone call.

\section{RESULTS}

In 2011, 54,099 interviews were conducted with adults in the group of capitals. Out of these, 28,625 had at least one health plan and 25,474 did not have health plans (Table 1). Data from Vigitel 2011 estimate that $47.4 \%$ of the population living in the capitals has at least one health plan, ranging from $26.1 \%$ (Macapá) and $64.5 \%$ (Vitória). The population of capitals in the South and the Southeast present more coverage, and the lowest numbers are in the North and in the Northeast. 
The result of the logistic regression shows that, from the age of 35 , the chances of an adult having a health insurance plan is higher when compared to the group aged 18 to 24 years old. The same can be observed for schooling: the higher the schooling, the higher the chances of an adult having a health plan when compared to the group with 0 to 8 schooling years (Table 2 ).

The group of adults with health plan has lower association in the indicators: smoking or excessive smoking (20 or more cigarettes a day); passive smoker in the household and at work; consumption of whole milk or soft drink five or more days a week; consumption of beans on five or more days a week; evaluation of health status considered to be poor and arterial hypertension. Physical activity during free time is more frequent in the group with

Table 1. Sample size per state capital, and health plan possession and health plan coverage per state capital according to Vigitel, 2011.

\begin{tabular}{l|c|c|c|c|c}
\multirow{2}{*}{ Capital } & \multicolumn{2}{|c|}{ Having a health plan } & \multirow{2}{*}{ Total } & \multicolumn{2}{c}{ Coverage of health plan } \\
\cline { 2 - 3 } Aracaju & No & Yes & & $\%$ & $95 \% \mathrm{Cl}$ \\
\hline Belém & 810 & 1191 & 2001 & 47.9 & $45.19-50.68$ \\
\hline Belo Horizonte & 890 & 1148 & 2038 & 46.2 & $43.47-49.01$ \\
\hline Boa Vista & 758 & 1247 & 2005 & 57.6 & $55.02-60.15$ \\
\hline Campo Grande & 1270 & 747 & 2017 & 26.1 & $23.61-28.69$ \\
\hline Cuiabá & 1006 & 990 & 1996 & 45.6 & $43.01-48.16$ \\
\hline Curitiba & 898 & 1102 & 2000 & 49.3 & $46.64-52.03$ \\
\hline Florianópolis & 838 & 1161 & 1999 & 56.0 & $53.49-58.49$ \\
\hline Fortaleza & 695 & 1305 & 2000 & 58.4 & $55.70-61.08$ \\
\hline Goiânia & 940 & 1062 & 2002 & 42.8 & $40.10-45.46$ \\
\hline João Pessoa & 908 & 1091 & 1999 & 51.1 & $48.53-53.66$ \\
\hline Macapá & 906 & 1094 & 2000 & 40.2 & $37.39-42.93$ \\
\hline Maceió & 1058 & 938 & 1996 & 29.5 & $25.10-33.88$ \\
\hline Manaus & 917 & 1084 & 2001 & 40.1 & $37.27-42.89$ \\
\hline Natal & 1176 & 838 & 2014 & 35.1 & $32.47-37.65$ \\
\hline Palmas & 882 & 1118 & 2000 & 45.1 & $42.28-47.87$ \\
\hline Porto Alegre & 920 & 1081 & 2001 & 42.1 & $39.23-44.92$ \\
\hline Porto Velho & 828 & 1185 & 2013 & 54.2 & $51.60-56.90$ \\
\hline Recife & 1036 & 963 & 1999 & 37.1 & $34.51-39.75$ \\
\hline Rio Branco & 918 & 1094 & 2012 & 46.2 & $43.50-48.94$ \\
\hline Rio de Janeiro & 1186 & 815 & 2001 & 29.7 & $27.23-32.17$ \\
\hline Salvador & 854 & 1145 & 1999 & 52.6 & $50.00-55.29$ \\
\hline São Luís & 1083 & 915 & 1998 & 38.2 & $35.76-40.71$ \\
\hline São Paulo & 1208 & 800 & 2008 & 30.8 & $28.38-33.28$ \\
\hline Teresina & 907 & 1092 & 1999 & 50.3 & $47.76-52.84$ \\
\hline Vitória & 917 & 1083 & 2000 & 41.0 & $38.29-43.77$ \\
\hline Distrito Federal & 678 & 1322 & 2000 & 63.5 & $60.92-66.05$ \\
\hline Total & 987 & 1014 & 2001 & 40.8 & $38.33-43.37$ \\
\hline & 25474 & 28625 & 54099 & 47.4 & $46.57-48.25$ \\
\hline
\end{tabular}


health plan, while those who do not have health plans are more active during commute and in the household. Having health insurance plans increases the chances of eating fruits, vegetables and greens (FVG), and of driving after drinking. Preventive examinations, such as mammography among women aged 50 to 69 years old, and the Pap test (to prevent uterine cervical cancer) among women aged between 25 and 59 years old, are more frequent among those with health plans. With regard to the following indicators: former smoker, intake of meat with excessive fat, abusive consumption of alcohol, excess weight, obesity and diabetes, these are not associated with the variable having a health plan (Table 3 ).

The population with health plans and lower schooling ( 0 to 8 years), compared to those with no health plan, presents less chances of smoking, smoking 20 cigarettes a day or more, drinking whole milk, performing physical activity during commute between work and the household, and in the household, and drinking alcohol abusively. On the other hand, it increases the chances of eating fruits, vegetables and greens (FVG), performing physical activity during free time, driving after drinking, more coverage of prevention examinations for breast cancer (women aged between 50 and 69 years old) and preventing uterine cervical cancer ( 25 to 59 years old) (Table 4 ). In the group of people with 9 to 11 schooling years, the population with health plans, in comparison to the population without health plans, present lower odds ratio for smoking, smoking 20 cigarettes a day or more, smoking passively in the household or at work, drinking whole milk, having lower prevalence of physical activity during commute and in the household, having higher prevalence of poor health status and having more arterial hypertension. On the other hand, it increases the chances of eating FVG, to perform more physical activities during free time, more coverage for the prevention of breast cancer among women aged between 50 and 69 years old and more coverage for the prevention of uterine cervical cancer among women aged between 25 and 59 years old. In the group with 12 schooling years or more, the population with health plans, compared

Table 2. Population coverage of health plans, according to age and education, Brazilian capitals, 2011. Odds ratio (OR) estimated by logistic regression model.

\begin{tabular}{c|c|c}
\multicolumn{2}{|c|}{ Variables } & \multicolumn{2}{c}{ OR } & $95 \% \mathrm{Cl}$ \\
\hline Age group & 1.00 & \\
\hline $18-24$ & 1.03 & $0.91-1.17$ \\
\hline $25-34$ & 1.27 & $1.12-1.44$ \\
\hline $35-44$ & 1.63 & $1.43-1.86$ \\
\hline $45-54$ & 1.95 & $1.69-2.25$ \\
\hline $55-64$ & 3.39 & $2.92-3.94$ \\
\hline $65-90$ & & \\
\hline Schooling & 1.00 & \\
\hline $0-8$ & 2.82 & $2.57-3.10$ \\
\hline $9-11$ & 11.58 & $10.36-12.95$ \\
\hline $12-20$ & &
\end{tabular}


Table 3. Comparison of the distribution of risk and protective factors of Chronic Non-Communicable Diseases with and without health insurance, among the 26 state capitals and the Federal District. Odds ratio (OR) estimated by logistic regression model.

\begin{tabular}{|c|c|c|c|c|c|c|}
\hline \multirow{3}{*}{ Indicators } & \multicolumn{4}{|c|}{ Having a health plan } & \multirow{3}{*}{$\mathrm{OR}_{\mathrm{adj}}$} & \multirow{3}{*}{$95 \% \mathrm{Cl}$} \\
\hline & \multicolumn{2}{|c|}{ Yes } & \multicolumn{2}{|c|}{ No } & & \\
\hline & Proportion & $95 \% \mathrm{Cl}$ & Proportion & $95 \% \mathrm{Cl}$ & & \\
\hline \multicolumn{7}{|l|}{ Smoking } \\
\hline Smoker & 10.07 & $9.29-10.85$ & 16.37 & $15.37-17.36$ & 0.66 & $0.59-0.74$ \\
\hline Former smoker & 21.30 & $20.33-22.27$ & 22.82 & $21.83-23.81$ & 0.99 & $0.91-1.09$ \\
\hline Smokes 20 or more cigarettes & 2.99 & $2.54-3.44$ & 4.93 & $4.33-5.52$ & 0.70 & $0.57-0.86$ \\
\hline $\begin{array}{l}\text { Passive smoker in the } \\
\text { household }\end{array}$ & 9.83 & $9.07-10.58$ & 12.67 & $11.83-13.51$ & 0.82 & $0.73-0.93$ \\
\hline Passive smoker at work & 9.29 & $8.57-10.01$ & 12.93 & $12.11-13.75$ & 0.82 & $0.73-0.93$ \\
\hline \multicolumn{7}{|l|}{ Consumption } \\
\hline FVG regularly & 39.98 & $38.85-41.12$ & 27.94 & $26.88-29.00$ & 1.36 & $1.26-1.47$ \\
\hline FVG recommended & 25.90 & $24.90-26.91$ & 18.36 & $17.42-19.29$ & 1.24 & $1.13-1.35$ \\
\hline Meat with excessive fat & 29.73 & $28.63-30.83$ & 34.93 & $33.75-36.10$ & 0.92 & $0.85-1.00$ \\
\hline Whole milk & 51.00 & $49.82-52.17$ & 60.29 & $59.13-61.45$ & 0.75 & $0.70-0.81$ \\
\hline Soft drink on five days or more & 25.86 & $24.78-26.95$ & 29.02 & $27.87-30.17$ & 0.91 & $0.83-0.99$ \\
\hline Beans on five days or more & 63.88 & $62.78-64.98$ & 70.96 & $69.95-71.98$ & 0.92 & $0.85-0.98$ \\
\hline \multicolumn{7}{|l|}{ Physical activity } \\
\hline In free time & 37.59 & $36.45-38.72$ & 26.18 & $25.15-27.22$ & 1.41 & $1.30-1.52$ \\
\hline Commuting & 12.37 & $11.53-13.21$ & 18.60 & $17.62-19.57$ & 0.66 & $0.59-0.73$ \\
\hline In the household & 30.11 & $29.05-31.18$ & 44.47 & $43.29-45.65$ & 0.63 & $0.59-0.68$ \\
\hline At work & 36.89 & $35.74-38.04$ & 45.29 & $44.08-46.49$ & 0.79 & $0.73-0.85$ \\
\hline Leisure or transportation & 27.49 & $26.45-28.54$ & 28.90 & $27.80-29.99$ & 0.88 & $0.82-0.96$ \\
\hline Inactive & 15.94 & $15.10-16.79$ & 13.97 & $13.16-14.79$ & 1.14 & $1.03-1.26$ \\
\hline \multicolumn{7}{|l|}{ Alcohol consumption } \\
\hline Abusive & 16.54 & $15.65-17.44$ & 16.50 & $15.59-17.41$ & 0.94 & $0.85-1.03$ \\
\hline Driving after drinking & 7.16 & $6.57-7.75$ & 3.60 & $3.19-4.01$ & 1.45 & $1.24-1.70$ \\
\hline \multicolumn{7}{|l|}{ Health } \\
\hline Excess weight & 49.56 & $48.34-50.78$ & 48.62 & $47.34-49.89$ & 1.05 & $0.97-1.13$ \\
\hline Obesity & 14.86 & $14.01-15.70$ & 16.68 & $15.75-17.61$ & 0.90 & $0.82-1.00$ \\
\hline Self-reported poor health status & 3.19 & $2.79-3.60$ & 5.77 & $5.26-6.29$ & 0.72 & $0.61-0.87$ \\
\hline \multicolumn{7}{|l|}{ Reported morbidity } \\
\hline Arterial hypertension & 22.79 & $21.87-23.71$ & 25.69 & $24.67-26.71$ & 0.86 & $0.78-0.94$ \\
\hline Diabetes & 6.30 & $5.74-6.86$ & 6.27 & $5.73-6.80$ & 1.03 & $0.89-1.20$ \\
\hline \multicolumn{7}{|l|}{$\begin{array}{l}\text { Breast cancer prevention } \\
\text { ( } 50 \text { to } 69 \text { years old) }\end{array}$} \\
\hline Mammography & 94.39 & $92.82-95.96$ & 83.09 & $81.04-85.14$ & 2.66 & $1.86-3.81$ \\
\hline $\begin{array}{l}\text { Mammography in the past two } \\
\text { years }\end{array}$ & 85.70 & $83.59-87.82$ & 63.39 & $60.69-66.09$ & 2.81 & $2.23-3.54$ \\
\hline \multicolumn{7}{|l|}{ Pap test ( 25 to 59 years old) } \\
\hline Pap test at any point in life & 91.58 & $90.65-92.52$ & 83.97 & $82.72-85.21$ & 1.69 & $1.42-2.00$ \\
\hline Pap test in the past three years & 87.88 & $86.70-89.06$ & 76.84 & $75.38-78.29$ & 1.72 & $1.47-2.02$ \\
\hline
\end{tabular}


Table 4. Distribution of risk and protective factors of Chronic Non-Communicable Diseases in the population with and without health insurance, according to levels of education in all of the 26 state capitals and the Federal District. Risk factors according to education, with plan and without plan.

\begin{tabular}{|c|c|c|c|c|c|c|c|c|c|c|c|c|}
\hline \multirow{3}{*}{ Variable } & \multicolumn{4}{|c|}{0 to 8 schooling years } & \multicolumn{4}{|c|}{9 to 11 years } & \multicolumn{4}{|c|}{12 years and more } \\
\hline & \multicolumn{4}{|c|}{ Health plan } & \multicolumn{4}{|c|}{ Health plan } & \multicolumn{4}{|c|}{ Health plan } \\
\hline & Yes & No & $\mathrm{OR}^{*}$ & $95 \% \mathrm{Cl}$ & Yes & No & $\mathrm{OR}^{*}$ & $95 \% \mathrm{Cl}$ & Yes & No & $\mathrm{OR}^{*}$ & $95 \% \mathrm{Cl}$ \\
\hline
\end{tabular}

Smoking

\begin{tabular}{|c|c|c|c|c|c|c|c|c|c|c|c|c|}
\hline Smoker & 12.18 & 20.67 & 0.66 & $0.59-0.74$ & 9.13 & 12.09 & 0.69 & $0.58-0.82$ & 9.63 & 10.21 & 0.88 & $0.67-1.16$ \\
\hline Former smoker & 32.79 & 29.1 & 0.99 & $0.91-1.09$ & 18.34 & 16.51 & 0.94 & $0.83-1.08$ & 16.97 & 14.14 & 1.02 & $0.80-1.29$ \\
\hline $\begin{array}{l}\text { Smokes } 20 \\
\text { or more cigarettes }\end{array}$ & 4.12 & 6.91 & 0.7 & $0.57-0.86$ & 2.51 & 2.82 & 0.78 & $0.57-1.06$ & 2.73 & 2.61 & 0.85 & $0.53-1.38$ \\
\hline $\begin{array}{l}\text { Passive smoker } \\
\text { in the household }\end{array}$ & 9.2 & 11.48 & 0.82 & $0.73-0.93$ & 11.08 & 14.23 & 0.82 & $0.69-0.98$ & 9.08 & 12.99 & 0.72 & $0.55-0.95$ \\
\hline Passive smoker at work & 11.02 & 12.77 & 0.82 & $0.73-0.93$ & 10.51 & 14.01 & 0.76 & $0.64-0.89$ & 7.15 & 9.84 & 0.75 & $0.56-1.00$ \\
\hline \multicolumn{13}{|l|}{ Consumption } \\
\hline FVG regularly & 37.81 & 27.53 & 1.36 & $1.26-1.47$ & 34.52 & 26.93 & 1.3 & $1.16-1.46$ & 46.18 & 33.61 & 1.52 & $1.30-1.79$ \\
\hline FVG recommended & 22.78 & 17.21 & 1.24 & $1.13-1.35$ & 22.73 & 18.69 & 1.19 & $1.05-1.36$ & 30.64 & 22.89 & 1.36 & $1.14-1.62$ \\
\hline Meat with excessive fat & 29.14 & 36.09 & 0.92 & $0.85-1$ & 32.71 & 34.09 & 1 & $0.9-1.12$ & 27.40 & 32.02 & 0.87 & $0.73-1.03$ \\
\hline Whole milk & 51.33 & 56.59 & 0.75 & $0.7-0.81$ & 58.15 & 63.83 & 0.84 & $0.76-0.94$ & 44.41 & 66.10 & 0.44 & $0.38-0.52$ \\
\hline $\begin{array}{l}\text { Soft drink on } \\
\text { five days or more }\end{array}$ & 22.55 & 26.57 & 0.91 & $0.83-0.99$ & 28.35 & 32.12 & 0.92 & $0.81-1.03$ & 25.64 & 30.05 & 0.86 & $0.72-1.03$ \\
\hline Beans on five days or & 70.38 & 73.4 & 0.92 & $0.85-0.98$ & 68.47 & 69.33 & 1 & $0.9-1.11$ & 55.83 & 64.49 & 0.75 & $0.64-0.87$ \\
\hline \multicolumn{13}{|l|}{ Physical activity } \\
\hline In free time & 25.02 & 19.67 & 1.41 & $1.3-1.52$ & 38.54 & 32.49 & 1.38 & $1.24-1.54$ & 44.37 & 36.02 & 1.48 & $1.26-1.74$ \\
\hline Commuting & 9.61 & 18.34 & 0.66 & 0.73 & 14.26 & 18.48 & 0.77 & & 2.35 & 20.28 & 0.59 & $0.47-0.75$ \\
\hline In the household & 42.15 & 46.78 & 0.63 & $0.59-0.68$ & 34.32 & 44.16 & 0.62 & $0.55-0.68$ & 19.06 & 34.01 & 0.44 & $0.37-0.51$ \\
\hline At work & 34.8 & 45.63 & 0.79 & $0.73-0.85$ & 42.72 & 45.9 & 0.92 & $0.83-1.03$ & 32.95 & 41.38 & 0.71 & $0.60-0.83$ \\
\hline Leisure or transportation & 19.96 & 26.07 & 0.88 & $0.82-0.96$ & 30.14 & 31.65 & 0.98 & $0.88-1.1$ & 29.69 & 33.04 & 0.89 & $0.75-1.05$ \\
\hline Inactive & 19.22 & 15.79 & 1.14 & $1.03-1.26$ & 13.28 & 11.68 & 1.09 & $0.93-1.28$ & 16.33 & 13.19 & 1.24 & $1.00-1.53$ \\
\hline \multicolumn{13}{|l|}{ Alcohol consumption } \\
\hline Abusive & 9.74 & 15 & 0.94 & $0.85-1.03$ & 16.69 & 18.17 & 0.94 & $0.82-1.07$ & 20.55 & 18.01 & 1.27 & $1.04-1.56$ \\
\hline Driving after drinking & 3.25 & 2.31 & 1.45 & $1.24-1.7$ & 5.25 & 4.35 & 1.22 & $0.97-1.53$ & 11.24 & 7.36 & 1.62 & $1.23-2.14$ \\
\hline \multicolumn{13}{|l|}{ Health } \\
\hline Excess weight & 57.48 & 53.94 & 1.05 & $0.97-1.13$ & 48.3 & 44.53 & 1.04 & $0.94-1.16$ & 46.33 & 39.25 & 1.20 & $1.03-1.40$ \\
\hline Obesity & 19.75 & 19.14 & 0.9 & $0.82-1$ & 13.99 & 14.62 & 0.85 & $0.74-0.99$ & 12.94 & 12.89 & 0.92 & $0.74-1.13$ \\
\hline $\begin{array}{l}\text { Self-reported } \\
\text { poor health status }\end{array}$ & 7.14 & 7.82 & 0.72 & $0.61-0.87$ & 2.36 & 3.82 & 0.56 & $0.43-0.74$ & 1.53 & 2.59 & 0.53 & $0.34-0.82$ \\
\hline \multicolumn{13}{|l|}{ Reported morbidity } \\
\hline Arterial hypertension & 41.07 & 34.32 & 0.86 & $0.78-0.94$ & 18.2 & 17.13 & 0.79 & $0.69-0.91$ & 15.80 & 13.38 & 0.90 & $0.72-1.12$ \\
\hline Diabetes & 13.81 & 9.17 & 1.03 & $0.89-1.2$ & 4.44 & 3.4 & 0.93 & $0.72-1.2$ & 3.42 & 2.07 & 1.15 & $0.74-1.78$ \\
\hline
\end{tabular}

Breast cancer prevention

(50 to 69 years old)

\begin{tabular}{|c|c|c|c|c|c|c|c|c|c|c|c|c|}
\hline Mammography & 90.91 & 81.86 & 2.66 & $1.86-3.81$ & 96.95 & 85.83 & 5.25 & $3.11-8.88$ & 96.89 & 89.14 & 3.83 & $1.36-10.81$ \\
\hline $\begin{array}{l}\text { Mammography in the } \\
\text { past two years }\end{array}$ & 80.15 & 60.98 & 2.81 & $2.23-3.54$ & 88.29 & 70.53 & 3.32 & $2.38-4.64$ & 91.10 & 67.65 & 4.95 & $2.79-8.81$ \\
\hline \multicolumn{13}{|l|}{ Pap test ( 25 to 59 years old) } \\
\hline Pap test at any point in life & 90.28 & 84.65 & 1.69 & $1.42-2$ & 91.21 & 82.3 & 1.97 & $1.55-2.5$ & 92.44 & 86.75 & 1.55 & $1.08-2.23$ \\
\hline $\begin{array}{l}\text { Pap test in the } \\
\text { past three years }\end{array}$ & 82.33 & 76 & 1.72 & $1.47-2.02$ & 87.57 & 76.75 & 1.95 & $1.58-2.42$ & 90.49 & 81.03 & 1.97 & $1.44-2.68$ \\
\hline
\end{tabular}

*OR adjusted for age and years of education. FVG: Fruits, vegetables and greens. 
to that with no health plans, presents less chances of smoking, smoking passively at the household and at work, drinking whole milk, eating beans on five days a week or more, performing physical activity during commute and in the household, and having a poor health status. On the other hand, it increases the chances of eating FVG, practicing physical activities during free time, drinking alcohol abusively, driving after drinking, presenting with excessive weight, more coverage for the prevention of breast cancer and uterine cervical cancer. The estimated prevalence in the prevention of breast cancer presents a variation coefficient superior to $30 \%$, data not shown, so it should be used carefully.

\section{DISCUSSION}

The Vigitel survey points out that about half the population in the capitals has health insurance plans, which increases with schooling and age. The study, in general, indicates that the population with health insurance plans presents higher prevalence of protective factors, such as healthy diet, practice of physical activities during free time, coverage of preventive cancer examinations, such as mammography and the Pap test, and lower prevalence of risk factors, such as smoking, physical inactivity, poor health evaluation and arterial hypertension. The abusive alcohol consumption, the intake of meat with excessive fat, excess weight, obesity and diabetes are not associated with the variable having a health insurance plan. After being stratified by schooling, these characteristics, in general, tend to maintain; those with health plans, regardless of schooling, usually present better indicators.

The population covered by health plans is concentrated in urban areas, in the capitals, in the most populous cities and in the South and Southeast regions of the country. These differences can be explained by the higher concentration of richness and income in these places, therefore, this is where most health insurance plans are sold ${ }^{5,15,16}$. Data from Vigitel also pointed out to higher coverage in the South and Southeast capitals. A study also showed that people with more schooling years (12 years or more) have more access to health plans, which is also confirmed by PNAD 5 . Studies show that schooling is strongly associated with income and health ${ }^{17,18}$. Other analyses also indicate that schooling is strongly associated with having a health insurance plan ${ }^{9,19-21}$.

Data from Vigitel 2011 show $47.4 \%$ of the coverage of health insurance plans in the group of the adult population of Brazilian state capitals and the Federal District, which is very close to $46.2 \%$, which was estimated by the National Health Agency (ANS ${ }^{22}$. It is worth to mention that the coverage of ANS regards the population aged 20 years old or more. However, after stratifying by capital, it is possible to see differences between coverage rates. Vigitel overestimates, in almost double, the coverage of health plans in the capitals Boa Vista, Macapá, Palmas, Rio Branco and Goiânia, while it underestimates it in São Paulo and Vitória (Table 2). These differences can occur due to the coverage of Vigitel in these capitals. The post-stratification weight tends to correct these tendencies, but it may not be able to elimitate them completely. 
Data indicate the increased coverage of health plane with age and higher chances of elderly people having health plans. This has been described in other studies6, and also in the System of Beneficiary Information (SIB), of $\mathrm{ANS}^{16}$, which reveals this age group needs to use these services more often ${ }^{15,23}$.

The population covered by health plans has, in general, more access to health services. Besides, there are inequalities in the access due to the unequal distribution of equipment per region, urban or rural, types of services and human resources ${ }^{5,24}$.

These characteristics have been described in other studies in the United States (USA) (BRFSS $)^{7,8}$ and in Brazil ${ }^{9}$. The last study was conducted in the metropolitan region of Belo Horizonte, and showed that individuals who have access to health insurance plans, in general, presented healthier habits, such as smoking less, practicing more physical activities during free time, eating five or more portions of fruits, vegetables and greens, and performing more preventive examinations 9 .

American studies show that users without health insurance coverage present more risks of NCDs and less access to health services ${ }^{7,8}$. In general, the worst performances are in the population that is not covered by health plans, young, non-white people, who are self-employed or unemployed, and individuals with low wages or low income $e^{7,8,25,26}$.

Also in the United States, the population who can access health plans performs more preventive services, such as mammography, colonoscopy and oncotic cytology ${ }^{7}$.

The protocol of the Ministry of Health, according to international rules of WHO, recommends that the Pap test should be taken every three years among women at reproductive age ${ }^{27}$. With regard to mammography, the orientation for the periodicity of the examination is every two years, at the age group of 50 to 69 years old, once the evidence concerning the effectiveness of this examination to reduce mortality caused by breast cancer is stronger in this age group ${ }^{28}$.

Data from Vigitel are similar to those found in BRFSS, showing higher chances of women who have health insurance plans performing preventive examinations, such as mammography and oncotic cytology, which could be explained by the facilitated access to diagnostic and preventive services in this population ${ }^{7,8}$. Studies from the Research about Sanitary Medical Care (AMS) point out to the increased offer of beds in the private system, as well as equipment, such as the one used for mammography ${ }^{29}$. This reality tends to change progressively, with the investment made by the Ministry of Health on the priority program to reduce breast and uterine cervical cancer ${ }^{30,31}$.

It is important to emphasize that the prevalence of mammography in the past two years in the population without health plans is lower, but it is already close to the $75 \%$ objective predicted in the National Plan to Tackle Non-Communicable Diseases for $2022^{2,32}$. The same goal has been reached in the population with health plans ${ }^{2,6,32}$. The differences concerning the coverage of oncotic cytology (Pap test) between the population with and without health plans are lower, since this examination is provided by the Unified Health System (SUS), in Primary Care. The goal of the Plan to confront NCDs, of reaching mean coverage of $85 \%$ in 2022, has been reached in the population with health plans, and is close to be reached in the population covered only by SUS $(77 \%)^{2,6,32}$. 
It is important to mention that differences in the population with and without health plans persist after stratification by schooling. However, schooling is an important factor concerning the access to these examinations: the coverage of mammography and oncotic cytology increases with schooling.

In 2008, the global prevalence of diabetes was estimated in $100 \%$, and the one of arterial hypertension, between 25 and $40 \%{ }^{3}$. The use of morbidity reported in Brazil can result in lower prevalence rates, and the study may underestimate the prevalence of self-reported diagnoses (hypertension and diabetes), since it reflects previous medical diagnoses, and therefore, the availability of services. Literature indicates advantages in this form of collection, since it is not invasive and has low cost, and the self-reported diagnosis of hypertension demonstrated to be sensitive, thus, being a good indicator ${ }^{33,34}$.

Hypertension was mostly diagnosed in the population without health plan and lower schooling, which can be explained by the more facilitated access to practices of health promotion, such as healthy diet and physical activity, besides the facilitated access to health services in the population with health insurance plans ${ }^{35,36}$. Besides, WHO points out that the prevalence of hypertension is higher in low and mid-income countries, but interventions in the public health field lead to the decreased prevalence of this disease in high income countries ${ }^{3}$.

There was no difference in the prevalence of diabetes among people with and without health plans. However, in relation to schooling, the ratio of diabetes was inversed, thus suggesting that schooling, proxy of socioeconomic level, be related to the more facilitated access to practices of health promotion, such as healthy diet, physical activity, besides more access to health services ${ }^{5}$.

The population covered by health plans usually presents better schooling and income and more access to information about the importance of healthy habits; besides, they have more access to spaces to practice physical activities, more resources to buy healthy food, like fruits, vegetables and greens, more knowledge about the harms of smoking, among others ${ }^{9}$. Different indicators of physical activity were assessed and, in general, they were all compatible with studies that point out to the practice of physical activity during free time associated with more schooling years, higher income and having a health insurance plan $^{9,37,38}$. It was possible to observe that, on the contrary, physical activity connected to commuting, household chores and work tasks is more associated with people with no health

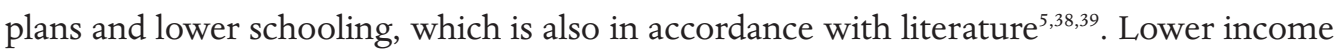
and schooling end up promoting the active transportation, like the use of bicycle, bus, collective transportation and dislocations on foot to work, besides the performance of tasks that require more energy at work and care with household cleaning. It is important to mention that the domains physical activity at work and in the household are not always associated with improvements to health, since they can lead to osteomuscular diseases due to excessive and intensive use ${ }^{39}$.

Even if the health status self-assessment can be a qualitative and subjective measure, it is also an important predictor of mortality and has been used internationally as an objective measurement of health condition ${ }^{40,41}$. In general, people with higher socioeconomic level and 
higher schooling, with more access to goods and services, tend to make a better evaluation of their own health status ${ }^{40,41}$. These characteristics can explain why people with health insurance plans make this better assessment. After stratification by schooling, populations with more schooling years still make the best evaluations.

No differences were found in relation to excess weight, obesity and abusive alcohol consumption. With regard to drinking and driving, the population with health insurance plans adopts this behavior more frequently, which can be justified by fact that owning a car is related to the higher socioeconomic status. Besides, Vigitel indicates that the population with more schooling years, proxy of income, adopts this practice more frequently ${ }^{10}$.

There are some limitations to this study. Among them, the fact of using telephone interviews, including only individuals who own a landline. This can reduce the participation of lower income populations, especially in the North and Northeast regions. However, this bias has been minimized by using the expansion factors from Census. The cross-sectional design of the study does not enable to establish a temporal cause-effect relationship. Therefore, it is not possible to state that the access to health plans leads to less exposure to risk if individuals who are more concerned about their own health look for coverage in these plans. Another limitation refers to the use of self-reported morbidity. The national and international experiences show that some self-reported variables, especially arterial hypertension and assessment of health status, can obtain good estimates, besides presenting advantages such as fast information, sensitivity and low $\operatorname{cost}^{33,41}$.

\section{CONCLUSION}

Vigitel allows monitoring the distribution of risk factors continuously, as well as the access to preventive examinations, reported morbidity of NCDs, and also the comparison between this distribution and the population who is beneficiary and non-beneficiary of health insurance plans. These data are essential to establish promotion and preventive measures, as well as to provide decision makers with subsidies to elaborate health programs.

To sum up, our results showed there are differences in lifestyles between adults who have insurance plans or not, therefore, it is possible to observe healthier habits amongst the former, regardless of schooling. The prevalence of using preventive examinations was also significantly higher among those with health plans, in comparison to people who exclusively depend on SUS, even after these results were stratified by schooling. 


\section{REFERENCES}

1. Schmidt MI, Duncan BB, Azevedo e Silva G, Menezes AM, Monteiro CA, BarretoSM, etal. Chronicnon-communicable diseases in Brazil: burden and current challenges. The Lancet 2011; 377(9781): 1949-61.

2. Brasil. Ministério da Saúde. Plano de ações estratégicas para o enfrentamento das doenças crônicas não transmissíveis (DCNT) no Brasil, 2011-2022. Brasília (DF); 2011.

3. Organização Mundial da Saúde. Global Status Report on Noncommunicable Diseases 2010. Genebra: WHO; 2011.

4. Organização Mundial da Saúde. Preventing chronic diseases: a vital investment. Genebra: WHO; 2005.

5. Brasil. Instituto Brasileiro de Geografia e Estatística. Pesquisa Nacional por Amostra de Domicílios (PNAD 2008). Um panorama da saúde no Brasil: acesso e utilização dos serviços, condições de saúde: 2008. Rio de Janeiro (RJ); 2010.

6. Malta DC, Morais Neto OL, Silva Junior JB. Apresentação do plano de ações estratégicas para o enfrentamento das doenças crônicas não transmissíveis no Brasil, 2011 a 2022. Epidemiol Serv Saúde 2001; 20(4): 425-38.

7. Ahluwalia IB, Bolen J, Garvin B. Health insurance coverage and use of selected preventive services by working age women, BRFSS 2006. J Womens Health (Larchmt) 2007; 16(7): 935-40.

8. Nelson KM, Chapko MK, Reiber G, Boyko EJ. The association between health insurance coverage and diabetes care; data from the 2000 behavior risk factor surveillance system. Health Serv Res 2005; 40(2): 361-72.

9. Lima-Costa MF. Estilos de vida e uso de serviços preventivos de saúde entre adultos filiados ou não a plano privado de saúde (inquérito de saúde de Belo Horizonte). Ciênc Saúde Coletiva 2004; 9(4): 857-64.

10. Brasil. Ministério da Saúde. Secretaria de Vigilância em Saúde. Vigitel Brasil 2011: Vigilância de fatores de risco e proteção para doenças crônicas por inquérito telefônico. Brasília; 2012.

11. Kalton G, Flores-Cervantes I. Weighting Methods. J Off Stat 2003; 19(2): 81-97.

12. Bernal RTI. Inquéritos por telefone: inferências válidas em regiões com baixa taxa de cobertura de linhas residenciais [Tese de Doutorado]. São Paulo: Universidade de São Paulo; 2011.

13. Izrael D, Hoaglin DC, Battaglia MP. A SAS Macro for Balancing a Weighted Sample; Proceedings of the Twenty-Fifth Annual SAS Users Group International Conference. 2000; Paper 275.
14. Paula GA. Modelos de Regressão com apoio computacional. Instituto de Matemática e Estatística. São Paulo (SP): Universidade de São Paulo; 2004.

15. Malta DC, Jorge AO. O mercado de saúde suplementar e análise dos dados das operadoras selecionadas. In: ANS. Duas faces da moeda: microrregulação e modelos assistenciais na saúde suplementar. Rio de Janeiro: Ministério da Saúde; 2005.

16. Brasil. Agência Nacional de Saúde Suplementar. Caderno de Informações de Saúde Suplementar. Março/ 2009.

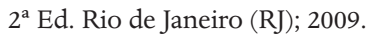

17. Brasil. Rede Interagencial de Informação em Saúde. Indicadores Básicos para a Saúde no Brasil: conceitos e aplicações. Brasília: Organização Pan Americana de Saúde; 2008.

18. Pincus T, Callahan LF. Associations of low formal education level and poor health status: behavioral, in addition to demographic and medical, explanations? J Clin Epidemiol 1994; 47(4): 355-61.

19. Bahia L, Costa AJ, Fernandes C, Luiz RR, Cavalcanti ML. Segmentação da demanda dos planos e seguros privados de saúde: uma análise das informações da PNAD/98. Ciênc Saúde Coletiva 2002; 7(4): 671-86.

20. Lima-Costa MF, Guerra HL, Firmo JO, Vidigal PG, Uchoa E, Barreto SM. he Bambuí Health and Aging Study (BHAS): private health plan and medical care utilization by older adults. Cad Saúde Pública 2002: 18(1): 177-86.

21. Lima-Costa MF. A escolaridade afeta, igualmente, comportamentos prejudiciais à saúde de idosos e adultos mais jovens?: Inquérito de Saúde da Região Metropolitana de Belo Horizonte, Minas Gerais, Brasil. Epidemiol Serv Saúde 2004; 13(4): 201-8.

22. Agência Nacional de Saúde Suplementar. Tabnet. Disponível em: http:/ /www.ans.gov.br/anstabnet/ cgi-bin/tabnet?dados/tabnet_br.def (Acessado em 11 de março de 2013).

23. Pinto LF, Soranz DR. Planos privados de assistência à saúde: cobertura populacional no Brasil. Ciênc Saúde Coletiva 2004; 9(1): 85-98.

24. Brasil. Comissão Nacional Sobre Determinantes Sociais da Saúde. Iniqüidades em saúde no Brasil, nossa mais grave doença. Rio de Janeiro: Fundação Oswaldo Cruz; 2006.

25. Hayward RA, Shapiro MF, Freeman HE, Corey $\mathrm{CR}$. Inequalities in health services among insured Americans. Do working-age adults have less access to medical care than the elderly? N Engl J Med 1988; 318: $1507-12$. 
26. Hagdrup NA, Simoes EJ, Brownson, RC. Health care coverage: traditional and preventive measures and associations with chronic disease risk factors. J Community Health 1997; 22(5): 387-99.

27. Brasil. Ministério da Saúde. Instituto Nacional do Cancer. Programa Nacional de Controle do Câncer do Colo do Útero [Internet]. Disponível em: http:/ / www2. inca.gov.br/wps/wcm/connect/acoes_programas/ site/home/nobrasil/programa_nacional_controle_ cancer_colo_utero (Acessado em 4 setembro de 2013).

28. Brasil. Ministério da Saúde. Instituto Nacional do Cancer. Programa Nacional de Controle do Câncer de Mama [Internet]. Disponível em: http://www2. inca.gov.br/wps/wcm/connect/acoes_programas / site/home/nobrasil/programa_controle_cancer_ mama (Acessado em 4 setembro de 2013).

29. Santos IS, Uga MA, Porto SM. O mix público-privado no Sistema de Saúde Brasileiro: financiamento, oferta e utilização de serviços de saúde. Ciênc Saúde Coletiva 2008; 13(5): 1431-40.

30. Brasil. Ministério da Saúde. Portaria n. 827 de 23 de julho de 2013. Inclui incremento de $44,88 \%$ no valor do componente SA do procedimento Mamografia bilateral para rastreamento da Tabela de Procedimentos, Medicamentos, Órteses, Próteses e Materiais Especiais do Sistema Único de Saúde (SUS). Diário Oficial da União. 2013 Jul 24; Seção 1:38.

31. Brasil. Portaria n. 1.504 de 23 de julho de 2013. Institui a Qualificação Nacional em Citopatologia na prevenção do câncer do colo do útero (QualiCito), no âmbito da Rede de Atenção à Saúde das Pessoas com Doenças Crônicas. Diário Oficial da União. 2013 Jul 24; Seção 1:31.

32. Malta DC, Silva JB Jr. O Plano de Ações Estratégicas para o Enfrentamento das Doenças Crônicas Não Transmissíveis no Brasil e a definição das metas globais para o enfrentamento dessas doenças até 2025: uma revisão. Epidemiol Serv Saúde 2013; 22(1): 151-64.
33. Lima-Costa MF, Peixoto SV, Firmo JO. Validade da hipertensão arterial auto-referida e seus determinantes (projeto Bambuí). Rev Saúde Pública 2004; 38(5): 637-42.

34. Vargas CM, Burt VL, Gillum RF, Pamuk ER. Validity of self-reported hypertension in the National Health and Nutrition Examination Survey III, 1988-1991. Prev Med 1997; 26(5 Pt 1): 678-85.

35. Chobanian AV, Bakris GL, Black HR, Cushman WC, Green LA, Izzo JL Jr, et al. Seventh report of the Joint National Committee on Prevention, Detection, Evaluation, and Treatment of High Blood Pressure. Hypertension 2003; 42(6): 1206-52.

36. Ferreira SR, Moura EC, Malta DC, Sarno F. Frequência de hipertensão arterial e fatores associados: Brasil, 2006. Rev Saude Publica 2009; 43(2): 98-106.

37. Florindo AA, Hallal PC, Moura EC, Malta DC. Prática de atividades físicas e fatores associados em adultos, Brasil, 2006. Rev Saúde Pública 2009; 43(2): 65-73.

38. Malta DC, Moura EC, Castro AM, Cruz DK, Morais Neto OL, Monteiro CA. Padrão de atividade física em adultos brasileiros: resultados de um inquérito por entrevistas telefônicas, 2006. Epidemiol Serv Saúde 2009; 18(1): 7-16.

39. Knuth AG, Malta DC, Dumith SC, Pereira CA, Morais Neto OL, Temporão JG, et al. Prática de atividade física e sedentarismo em brasileiros: resultados da Pesquisa Nacional por Amostra de Domicílios (PNAD) 2008. Ciênc Saúde Coletiva 2011; 16(9): 3697-705.

40. Molarius A, Berglund K, Eriksson C, Lambe M, Nordström E, Eriksson H, et al. Socioeconomic conditions, lifestyle factors, and self-rated health among men and women in Sweden. Eur J Public Health 2007; 17(2): 125-33.

41. Dachs JN, Santos AP. Auto-avaliação do estado de saúde no Brasil: análise dos dados da PNAD/2003. Ciênc Saúde Coletiva 2006; 11(4): 887-94.

Received on: 11/09/2013

Final version presented on: 02/17/2014

Accepted on: 02/17/2014 